\title{
KEMITRAAN GUGUS TUGAS DAN WARGA DALAM MENGHADAPI PANDEMI COVID-19
}

Catur Ragil Sutrisno ${ }^{1}$, Amalia Ilmiani ${ }^{2}$, Titi Rahayu Prasetiani ${ }^{3}$

123Fakultas Ekonomi, Universitas Pekalongan

Email: caturunikal@gmail.com

\section{RINGKASAN}

Corona Virus Disease (Covid-19) yang muncul di penghujung tahun 2019 dengan cepat menyebar menjadi pandemi. Indonesia termasuk negara yang terkena dampak pandemi itu. Puluhan ribu orang positif terkena Covid-19 dan ribuan diantaranya meninggal dunia. Hal ini membutuhkan penangan super serius dan melibatkan banyak pihak. Diantara garda depan perlawanan terhadap Covid-19 adalah gugus tugas di tingkat RT, termasuk RT 01 RW 07 Kelurahan Sokanegara Kecamatan Purwokerto Timur Kabupaten Banyumas. Kegiatan yang dilaksanakan gustu beragam jenisnya. Sosialisasi ke warga tentang Covid-19 dan bahayanya, pemasangan tempat cuci tangan di tiap mulut gang, pembagian masker, penyemprotan disinfektan secara rutin, pendampingan keluarga dari warga berstatus ODP, pendataan warga terdampak dan penyaluran bantuan. Kegiatan sekaligus gerakan bersama ini dilakukan untuk mencegah penyebaran Covid-19.

\section{Kata kunci: Covid-19; Gugus Tugas; Pencegahan Penyebaran}

\section{A. Latar Belakang}

Corona Virus Disease (Covid-19) yang muncul di penghujung tahun 2019 dengan cepat menyebar menjadi pandemi. Meski bukan corona yang pertama, tetapi tetap saja Covid-19 menjadi hantu yang menakutkan bagi banyak pihak. Dari sisi jenisnya, Yuliana (2020) menyebutkan bahwa Coronavirus merupakan virus RNA strain tunggal positif, berkapsul dan tidak bersegmen. Coronavirus termasuk ordo Nidovirales, keluarga Coronaviridae. Struktrur coronavirus membentuk struktur seperti kubus dengan protein S berlokasi di permukaan virus. Dilihat dari penyebarannya, hampir seluruh dunia merasakan penularannya. Indonesia termasuk negara yang terkena dampak pandemi itu. Hal ini menimbulkan keprihatinan mendalam. Nyawa manusia berjatuhan di hampir semua daerah, tidak mengenal suku, agama, ras maupun golongan. Berdasarkan infografis Gugus Tugas Badan Nasional Penanggulangan Bencana (BNPB), sampai pertengahan 15 Juli 2020 pukul 12.00 WIB tercatat 80.094 dinyatakan positif, 39.050 sembuh dan 3.797 meninggal dunia di 463 kabupaten/kota yang terdapat pada 43 
provinsi. Selain itu, dampak besar yang ditimbulkan hampir ke semua sektor. Pendidikan, ekonomi, pariwisata, sosial, bahkan politik terkena imbasnya.

Hal ini membutuhkan penangan super serius dan melibatkan banyak pihak. Tanggap darurat penanganan dilakukan pemerintah bekerjasama dengan seluruh elemen masyarakat. Diantara garda depan perlawanan terhadap Covid-19 adalah gugus tugas di tingkat RT, termasuk RT 01 RW 07 Kelurahan Sokanegara Kecamatan Purwokerto Timur Kabupaten Banyumas. Kegiatan yang dilaksanakan gustu beragam jenisnya. Sosialisasi ke warga tentang Covid-19 dan bahayanya, pemasangan tempat cuci tangan di tiap mulut gang, pembagian masker, penyemprotan disinfektan secara rutin, pendampingan keluarga dari warga berstatus ODP, pendataan warga terdampak dan penyaluran bantuan. Kegiatan sekaligus gerakan bersama ini dilakukan untuk mencegah penyebaran Covid-19.

Hal ini sebagai bentuk peran serta sekaligus pemberdayaan masyarakat. Dalam buku Pedoman Pemberdayan Masyarakat dalam Pencegahan Covid-19 di Tingkat RT/RW/Desa yang diterbitkan Kementerian Kesehatan Republik Indonesia (2020), disebutkan bagaimana masyarakat diberdayakan dalam penanganan Covid-19, pembagian tugas dalam pencegahan, informasi apa yang perlu disampaikan dan cara penyampaiannya, pengorganisasian masyarakat dalam pemenuhan logistik, dan pelaporan. Semuanya tidak lepas dari tanggungjawab gugus tugas.

\section{B. Metode Pelaksanaan}

Kegiatan gugus tugas percepatan penanganan Covid-19 RT 01 RW 07 Kelurahan Sokanegara Kecamatan Purwokerto Timur mulai efektif berjalan pada bulan Maret 2020. Secara kelembagaan tim gustu disahkan melalui Keputusan Lurah Sokanegara Nomor 360/10/Tahun 2020 tertanggal 2 April 2020. Tim wajib berkoordinasi dan melaporkan tugasnya kepada Lurah selaku Ketua Gugus Tugas Percepatan Penanganan Covid-19 tingkat Kelurahan. Diantara tugas gugus tugas RT yaitu: aktif menginformasikan himbauan/kebijakan pemerintah terkait dengan kewaspadaan dan pencegahan Covid-19, aktif mendata warga baik yang keluar maupun masuk di ingkungan RT dan melaporkan 
kepada lurah, melaporkan kepada lurah jika terdapat warga yang mempunyai gejala terkena virus, melaporkan setiap kegiatan yang dilakukan oleh Gugus Tugas RT kepada lurah, menciptakan situasi kondusif di kelompok masing-masing, dan menyampaikan laporan kejadian mendesak sewaktu-waktu jika diperlukan. Berdasarkan hal tersebut, metode pelaksanaan kegiatan adalah kolaborasi lapang antar komponen dalam bentuk Paticipatory Rural Appraisal (PRA). PRA adalah suatu metode pendekatan dalam proses pemberdayaan dan peningkatan partisipasi masyarakat, yang tekanannya pada keterlibatan masyarakat dalam keseluruhan kegiatan pembangunan.

\section{Hasil dan Pembahasan}

Kegiatan yang dilaksanakan gustu beragam jenisnya. Setelah tim Gugus tugas RT 01 RW 07 terbentuk maka koordinasi di tingkat RT, RW sampai kelurahan dilakukan dengan melibatkan Babinsa dan Babinkamtibmas. Hal ini dalam rangka menyamakan persepsi mengenai penanganan Covid-19 dan penyusunan program kerja. Intensitas koordinasi makin sering dilakukan seiring makin intensifnya kegiatan dan peningkatan kasus positif Covid-19 di Indonesia. Setiap ada perkembangan informasi, ketua gustu segera mengumpulkan anggota gustu untuk membahas tindak lanjutnya, dan jika diperlukan mengundang pengurus RT lain dan ketua RW. Dalam konteks organisasi, mekanisme pengkoordinasian memungkinkan anggota organisasi untuk tetap mengarahkan aktivitasnya kearah pencapaian tujuan organisasi dan mengurangi ketidakefisienan serta konflik yang merusak. Pengkoordinasian dimaksudkan agar para manajer mengkoordinir sumber daya manusia dan sumber daya lain yang dimiliki organisasi tersebut. Kekuatan suatu organisasi tergantung pada kemampuannya untuk menyusun berbagai sumber dayanya dalam mencapai suatu tujuan (Morlian, 2016).

Selain koordinasi yang rutin dilakukan oleh gustu, program kerja gustu meliputi: 
a. Sosialisasi ke warga tentang Covid-19 dan bahayanya serta kebijakan pemerintah.

Merebaknya kasus orang terinfeksi Covid-19 yang kemudian menjadi wabah dan pandemi perlu diketahui seluruh warga. Hal ini supaya warga mengenal virus dan bahayanya, serta gejala yang yang ditimbulkan dan

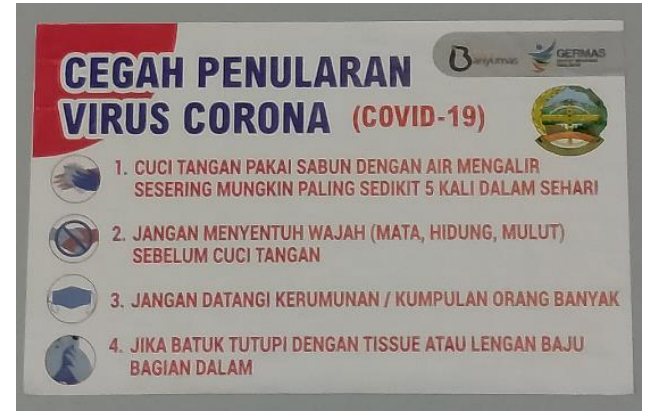

Gambar 1. Stiker sosialisasi yang ditempel di tembok warga antisipasinya. Oleh karena itu, penting untuk dilakukan sosialisasi untuk meningkatkan pengetahuan warga. Peran sosialisasi dibuktikan dalam penelitian Abdullah \& Nasionalita (2018). Hasil penelitiannya menunjukkan pengaruh yang signifikan dari sosialisasi diseminasi informasi terhadap pengetahuan pelajar di SMKN 1 Pangandaran. Berdasakan dari analisis koefisien yang dilakukan diperoleh nilai sebesar 0,497. Sehingga, sosialisasi "Diseminasi Informasi Melalui Media Jukrak" yang dilakukan oleh Divisi Komunikasi dan Publik Diskominfo Provinsi Jawa Barat berpengaruh sebesar 49,7\% terhadap pengetahuan pelajar di SMKN 1 Pangandaran. Demikian juga penelitian Lestari \& Nurhayat (2015) yang bermaksud mengungkap bagaimana strategi komunikasi yang tepat dalam menyampaikan pengetahuan dasar tentang HiV/Aids dalam mengendalikan penyebaran dan menurunkan jumlah kasus baru HiV/Aids bagi warga Kota Sukabumi. Hasilnya menunjukkan bahwa bentuk komunikasi yang efektif untuk menyampaikan pengetahuan dasar HIV/Aids adalah dengan komunikasi kelompok primer, kemasan isi pesan disampaikan dengan pemilihan kata yang tepat, menggunakan kata-kata pendek dan konkrit, menggunakan katakata secara ekonomis dan positif, memakai jargon yang up to date, menggunakan gaya percakapan, menyusun kalimat secara ringkas dan aktif, kata-kata yang disampaikan berupa imbauan yang bersifat rasional dan emosional, dan imbauan motivasional. Sedangkan media yang dianggap efektif adalah media audiovisual seperti video dan sosial media. 


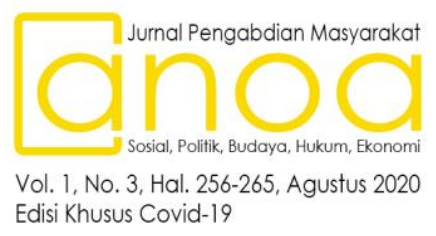

Mengingat pentingnya sosialisasi Covid-19, Gugus tugas di RT 01 RW 07 Sokanegara melakukan sosialisasi dengan beberapa cara. Selain pemasangan striker di tiap rumah warga, juga menyebarkan informasi melalui media sosial khususnya WhatsApp Group (WAG) RT. Kemajuan teknologi membantu tim untuk mempercepat penyampaian informasi dan memberi pemahaman kepada warga. Pemutusan rantai penyebaran Covid-19 memerlukan kolaborasi berbagai pihak, pemerintah, perguruan tinggi, komunitas dan masyarakat. Adanya protokol jarak fisik (phsycal dintancing) tidak menghalangi kegiatan sosialisasi, karena dapat dilakukan menggunakan perangkat teknologi digital (Wiratmo, 2020).

b. Pemasangan tempat cuci tangan di tiap mulut gang dan depan rumah warga.

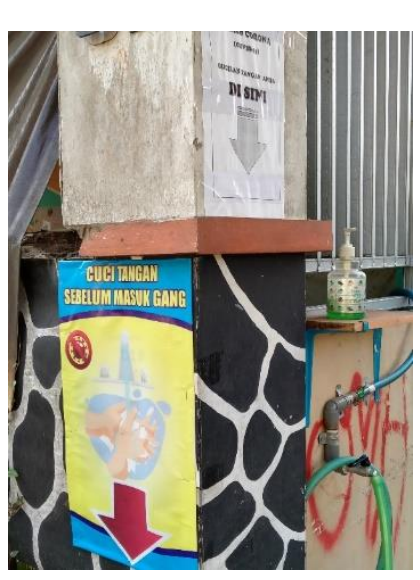

Gambar 2. Himbuaun Cuci Tangan Sebelum masuk Gang
Pola Hidup Bersih dan Sehat (PHBS) merupakan perilaku kesehatan yang dilakukan atas kesadaran diri dan keluarga, dan menjadi salah satu kunci pertahanan diri terhadap Covid-19. Perilaku ini dapat menciptakan lingkungan yang bersih dan mengurangi risiko terkena penyakit. Diantara aktivitas PHBS adalah rajin mencuci tangan memakai sabun (Cuci Tangan Pakai Sabun/CTPS). Selain menghimbambau warga membuat tempat cuci tangan di depan rumah masing-masing, Gugus tugas RT 01 RW 07 juga membuat dan memasang kran air beserta sabun di tiap mulut gang. Orang yang masuk wilayah RT dihimbau untuk mencuci tangan memakai sabun. Himbauan ini ditulis menggunakan banner berdekatan dengan kran air. Sesuai dengan Pedoman Penanganan Cepat Medis dan Kesehatan Masyarakat Covid-19 di Indonesia (Kementerian Kesehatan Republik Indonesia, 2020a) dan dipublikasikan oleh Gugus Tugas Percepatan Penanganan Covid-19 Kementerian Kesehatan RI, Ketua RT-RW dan Kader Kesehatan diharapkan dapat mendorong kesiapan dan partisipasi masyarakat untuk melakukan upaya kebersihan personal dan kebersihan rumah sebagai bagian dari perwujudan Gerakan Masyarakat Hidup Sehat. Gerakan PHBS berlaku untuk semua kalangan, 
baik tua maupun muda termasuk anak-anak. Apalagi orang tua dan anak-anak termasuk kalangan yang rentan terhadap penularan Covid-19. Artikel Zukmadini, et al(2020) menunjukkan bahwa anak-anak termasuk juga anak-anak yatim piatu yang tinggal di panti asuhan sangat rentan terhadap penularan Covid-19. Oleh karena itu kegiatan yang dilaksanakan bertujuan untuk memberikan edukasi dan pendampingan kepada anak-anak panti asuhan untuk menerapkan pola perilaku hidup bersih dan sehat (PHBS) agar terhindar dari penularan Covid-19.

c. Pembagian masker.

Masker menjadi barang yang banyak dicari selama pandemi. Hal ini disebabkan adanya himbauan untuk selalu memakai masker saat keluar rumah sebagai bentuk perlindungan diri dari penyebaran Covid-19. Bahkan Menteri Dalam Negeri membuat Surat Edaran (SE) yang berisi himbauan kepada pemerintah daerah untuk membuat Peraturan Daerah (Perda) tentang kewajiban menggunakan masker beserta sanksinya. Dalam Pedoman Umum Menghadapi Pandemi Covid-19 Bagi Pemerintah Daerah yang diterbitkan Kementerian Dalam Negeri (2020) disebutkan bahwa penggunaan masker adalah efektif karena tujuan memakai masker adalah untuk memblokir 'pembawa' yang mentransmisikan virus, daripada secara langsung memblokir virus. Mengenakan masker dengan benar dapat secara efektif memblokir tetesan pernapasan dan karenanya mencegah virus masuk langsung ke dalam tubuh. Perlu diingatkan bahwa tidak perlu memakai respirator KN95 atau N95. Masker bedah biasa dapat menghalangi sebagian besar virus yang membawa tetesan memasuki saluran pernapasan. Surat Edaran Mendagri ditindaklajuti oleh beberapa pemerintah daerah

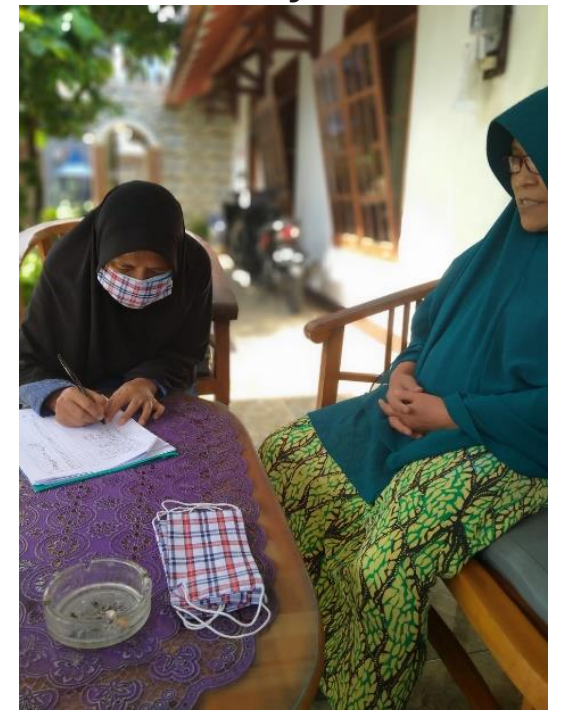

Gambar 3. Pembagian masker ke warga dengan menerbitkan perda, seperti dilakukan Pemerintah Kabupaten Banyumas yang menerbitkan Peraturan Daerah Nomor 2 Tahun 2020 tentang Pencegahan 
dan Penanggulangan Penyakit di Kabupaten Banyumas. Konsekuensinya, selain menerapkan sanksi bagi pelanggarnya, pemerintah Kabupaten Banyumas juga membagi masker gratis kepada seluruh warga yang didistribusikan melalui pemerintah desa/kelurahan dibantu gugus tugas di tingkat RT. Hal ini menunjukkan komitmen bersama pemerintah daerah dan gugus tugas dalam upaya pencegahan penyebaran Covid-19. Gugus tugas di RT 01 RW 07 membagikan masker kepada warga dengan mendatangi rumah warga. Kepala keluarga atau yang mewakili menerima masker dan membubuhkan tanda terima di formulir yang telah disediakan gugus tugas.

d. Penyemprotan disinfektan secara rutin.

Cara yang dapat dilakukan untuk mencegah penularan dan penyebaran Covid-19 diantaranya dengan senantiasa menjaga kebersihan dari diri dan lingkungan. Menjaga kebersihan diri dan lingkungan dapat dilakukan dengan cara menggunakan antiseptik dan desinfektan. Antiseptik merupakan zat yang dapat menghambat pertumbuhan dan perkembangan mikroorganisme tanpa harus membunuh mikroorganisme tersebut di jaringan hidup. Antiseptik biasanya mengandung alkohol, chlorhexidine, dan anilides. Desinfektan merupakan zat yang dapat membunuh patogen di lingkungan. Desinfektan biasanya mengandung glutaraldehid dan formaldehid. Penggunaan zat-zat tersebut sebelumnya lebih menjadi tanggungjawab tenaga medis, namun untuk sekarang penggunaan zatzat tersebut dapat digunakan tidak hanya di rumah sakit, namun di rumah pun akan sering digunakan (Larasati \& Haribowo, 2020).

Meskipun tingkat efektifitasnya tidak diketahui secara pasti, namun Gugus tugas RT 01 RW 07 tetap melakukan penyemprotan secara rutin minimal sepekan sekali selama pandemi dan berkurang setelah berlakunya normal baru. Hal ini dilakukan selain untuk menjaga kebersihan lingkungan, juga untuk

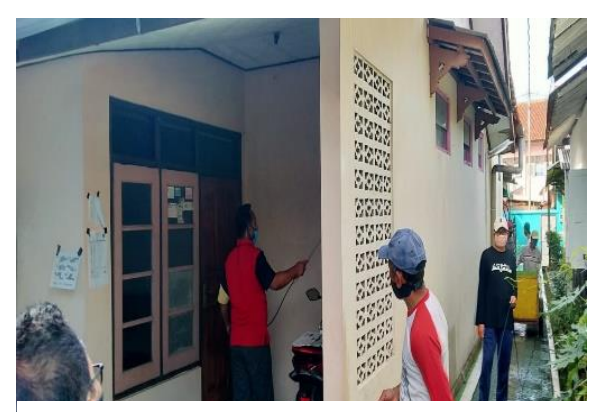

Gambar 4. Penyemprotan disinfektan 
memberi kenyamanan dan ketenangan warga. Harapannya, kenyamanan dan ketenangan warga dapat meningkatkan imunitas sehingga pertahanan fisiknya menjadi kuat dari serangan virus.

e. Pendampingan keluarga warga berstatus terkonfirmasi positif.

Salah satu tugas gugus tugas adalah melaporkan kepada lurah jika terdapat warga yang mempunyai gejala terkena virus. Hal ini untuk mempercepat penanganan lebih lanjut oleh pihak berwenang. Saat salah seorang warga diduga terinveksi

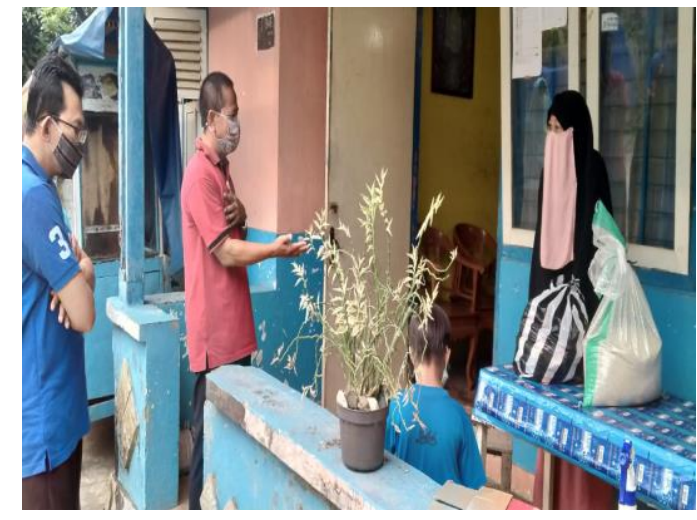

Gambar 5. Penyerahan Bantuan untuk Keluarga terkonfirmasi positif virus berdasarkan hasil reaksi tes rapid yang dilakukan petugas kesehatan dan dilakukan isolasi di rumah sakit, gugus tugas segera menindaklanjuti dengan melakukan koordinasi dengan pihak kelurahan dan pengurus RT. Keluarga warga yang terkonfirmasi positif tersebut harus didampingi untuk menguatkan psikologisnya sekaligus memberikan

bantuan sembako untuk kebutuhan sehari-hari. Bantuan sembako diberikan pihak pemerintah daerah melalui kelurahan dan bantuan yang berasal dari masjid dan RT.

f. Pendataan warga terdampak dan penyaluran bantuan.

Dampak pandemi Covid-19 di hampir semua sektor kehidupan dirasakan oleh seluruh lapisan masyarakat. Selain sektor kesehatan dan pendidikan, sektor ekonomi sangat dirasakan dampaknya oleh masyarakat. Ada yang terkena PHK, tidak dapat berjualan karena karena akibat aktivitas di luar yang dibatasi, jasa transportasi juga terhenti sehingga awaknya tidak mendapat penghasilan. Untuk meringankan beban warga yang terkena dampak Covid-19, gugus tugas melakukan langkah-langkah strategis sebagai berikut:

- Mendata warga terdampak secara ekonomi. Warga yang masuk dalam pendataan inilah warga yang terdampak pandemi secara khusus, misalnya 
kategori miskin, kena PHK, tidak dapat penghasilan lagi karena tidak bekerja dan sejenisnya. Mereka yang mendapat prioritas untuk diajukan mendapat bantuan, baik dari pemerintah maupun pihak lainnya. Secara umum, semua warga terdampak pandemi, namun ada skala prioritas untuk jenis bantuan tertentu.

- Menyalurkan bantuan berupa sembako kepada warga terdampak. Sembako yang disalurkan terdiri dari bantuan pemerintah Kabupaten melalui Dinas Sosial, sembako bantuan dari Masjid Al Fattah, dan sembako bantuan dari Masjid Jenderal Soedirman. Sembako yang berasal dari pemerintah dan Masjid Jenderal Soedirman diprioritaskan untuk warga terdampak khusus. Hanya warga yang tertentu, yang masuk pertimbangan tim gugus tugas, yang mendapatkan bantuan ini. Jumlahnya relatif sedikit.

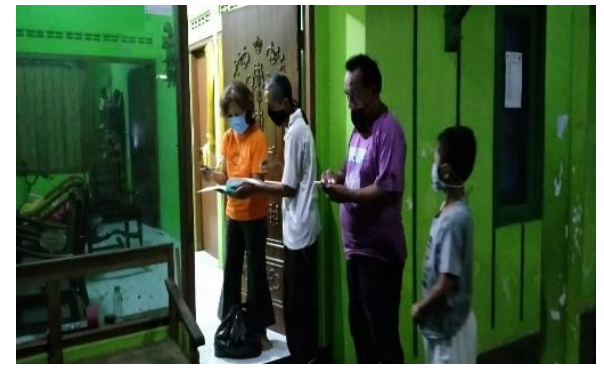

Gambar 6. Penyaluran Bantuan Sembako

Sedangkan bantuan sembako yang berasal dari Masjid Al Fattah diperuntukkan ke hampir semua warga. Sembako ini dibagikan dua kali, sehingga warga cukup terbantu dengan penyalurannya.

\section{Kesimpulan}

Kemitraan gugus tugas dengan pemerintah dan warga menjadi hal penting dalam menghadapi pandemi Covid-19. Sinergi yang dilakukan selain bertujuan untuk mencegah dan mengurangi penyebaran virus juga dapat mengurangi beban yang dirasakan warga akibat pandemi.

\section{E. UCAPAN TERIMAKASIH}

Terima kasih tim sampaikan kepada seluruh anggota gustu, seluruh warga RT 01 RW 07 Kelurahan Sokanegara, Ketua RT 01 RW 07 beserta pengurus, Ketua RW 07, Babinsa, Babinkamtibmas dan Lurah Sokanegara Kecamatan Purwokerto Timur. 


\section{DAFTAR PUSTAKA}

Abdullah, N. N., \& Nasionalita, K. (2018). Pengaruh Sosialisasi Terhadap Pengetahuan Pelajar Mengenai Hoax (Studi Pada Program Diseminasi Informasi Melalui Media Jukrak Di SMKN 1 Pangandaran). CHANNEL: Jurnal Komunikasi, 6(1), 106-119. https://doi.org/10.12928/channel.v6i1.10217

Kementerian Dalam Negeri. (2020). Pedoman Umum Menghadapi Pandemi COVID-19 Bagi Pemerintah Daerah; Pencegahan, Pengendalian, Diagnosis dan Manajemen. In Tim Kerja Kementerian Dalam Negeri untuk Dukungan Gugus Tugas COVID-19. https://doi.org/10.1017/CBO9781107415324.004

Kementerian Kesehatan Republik Indonesia. (2020a). Pedoman Penanganan Cepat Medis dan Kesehatan Masyarakat Covid-19 di Indonesia. In Gugus tugas percepatan penanganan covid-19.

Kementerian Kesehatan Republik Indonesia. (2020b). Pedoman Permberdayaan Masyarakat dalam Pencegahan Covid-19 di RT/RW/Desa. In Direktorat Promosi Kesehatan dan Pemberdayaan Masyarakat, Direktorat Jenderal Kesehatan Masyarakat. file://C:/Users/User/Downloads/fvm939e.pdf

Larasati, A. L., \& Haribowo, C. (2020). Penggunaan Desinfektan dan Antiseptik Pada Pencegahan Penularan Covid-19 di Masyarakat. Majalah Farmasetika, 5(3), 137-145. https://doi.org/10.24198/mfarmasetika.v5i3.27066

Lestari, Y., \& Nurhayat, I. (2015). Sosialisasi Pengetahuan Dasar Komprehensif Hiv / Aids. Komunikasi, IX(02), 13-28.

Morlian, A. (2016). Peranan Koordinasi Terhadap Produktivitas Kerja Pegawai Pada Kantor Dinas Pekerjaan Umum Provinsi DKI Jakarta. Jurnal AKP, 6(1), 18-27. https://doi.org/10.33558/akp.v6i1.581

Wiratmo, L. B. (2020). Sosialisasi Pemutusan Rantai Penyebaran Covid-19 Di Kelurahan Tlogosari Kulon Kota Semarang. Jurnal Pengabdian Pada Masyarakat, 8(1, Mei), 5765.

Yuliana. (2020). Corona virus diseases (Covid -19); Sebuah tinjauan literatur. Wellness And Healthy Magazine, 2(1, February), 187 - 192. https://doi.org/10.2307/j.ctvzxxb18.12

Zukmadini, A. Y., Karyadi, B., \& Kasrina. (2020). Edukasi Perilaku Hidup Bersih dan Sehat (PHBS) dalam Pencegahan COVID-19 Kepada Anak-Anak di Panti Asuhan. Jurnal Pengabdian Magister Pendidikan IPA, 3(1), 68-76. https://doi.org/10.29303/jpmpi.v3i1.440 